\title{
REUIEW DERMATOLOgY
}

กORTH CLIn ISTARB 2019;6(1):93-99

doi: $10.14744 /$ nci.2018.75010

\section{Diagnosis and treatment of urticaria in primary care}

\author{
(D) Melek Aslan Kayiran, (1) Necmettin Akdeniz \\ Department of Dermatology, Istanbul Medeniyet University Faculty of Medicine Goztepe Training and Research Hospital, Istanbul, Turkey
}

\begin{abstract}
Urticaria, also known as hives among people, is a very common disease characterized by erythematous, edematous, itchy, and transient plaques that involve skin and mucous membranes. It is classified as acute spontaneous urticaria, chronic spontaneous urticaria, chronic inducible urticaria, and episodic chronic urticaria. Many factors such as infections, medicines, food, psychogenic factors, and respiratory allergens are accused of etiology, but sometimes, it is idiopathic. Clinical presentation involves red, swelling, and itchy plaques. The lesions usually resolve spontaneously within $2-3 \mathrm{~h}$ without a trace. The patients are sometimes confronted with an angioedema that can also involve the respiratory tract. In this case mucous membranes, such as eyelids, lips, swell with some pain and burning sensation. If respiratory tracts are involved, it may be life threatening and should be treated urgently. The diagnosis is usually straightforward, urticarial vasculitis, drug eruptions, viral eruptions, and urticaria pigmentosa must also be considered. $\mathrm{H} 1$ antihistamines and, sometimes, short-term systemic corticosteroids are preferred for the treatment; $\mathrm{H} 2$ antagonists may be added during resistant cases, although other treatment options, such as omalizumab, cyclosporine, and leukotriene receptor antagonists, may be considered during missed events.
\end{abstract}

Keywords: Angioedema; treatment; urticaria.

Cite this article as: Aslan Kayiran M, Akdeniz N. Diagnosis and treatment of urticaria in primary care. North Clin Istanb 2019;6(1):93-99.

U rticaria is a disease characterized by erythematous, edematous, itchy and transient urticarial plaques, and covering the skin and mucous membranes. Also known as hives among people. It is a very common entity. $8.8-20 \%$ of individuals in the community experience an attack of urticaria at least once in their lifetime [1]. It can be seen in all ages and sexes but is slightly more common in young adults. In $40-50 \%$ of the patients, urticaria and angioedema are seen in combination, only urticaria or angioedema is seen in $40 \%$ and $20 \%$ of the people, respectively [2].

\section{Classification (Table 1)}

Acute spontaneous urticaria

It lasts $<6$ weeks [3].

\section{Chronic spontaneous urticaria (CSU)}

It recurs at least twice a week and lasts $>6$ weeks [3].

\section{Physical urticaria (chronic inducible urticaria)}

It emerges due to etiological factors as dermographism, cold, hot, vibration, pressure, and solar factors. It constitutes $20-30 \%$ of chronic urticaria [4].

\section{Episodic chronic urticaria}

It lasts $>6$ weeks but recurs $<2$ times per week [5].

It should be kept in mind that CSU and physical urticaria can be seen together. CSU is most commonly associated with dermatographic urticaria and late pressure urticaria [2].

\section{Pathogenesis}

The main mechanism in the formation of urticaria is the release of various mediators from mast cells. Type $1 \mathrm{im}$ munoglobulin ( $\mathrm{Ig}$ ) E-dependent hypersensitivity reaction is seen in acute urticaria. The antigen entering the body binds to specific antibodies on mast cells and ba-

Received: November 23, 2017 Accepted: January 27, 2018 Online: February 14, 2019

Correspondence: Dr. Melek Aslan KAYIRAN. Istanbul Medeniyet Universitesi Tip Fakultesi, Goztepe Egitim ve Arastirma Hastanesi, Deri ve Zührevi Hastaliklar Anabilim Dali, Istanbul, Turkey.

Tel: +90 5325232873 e-mail: melekaslan@gmail.com

(c) Copyright 2019 by Istanbul Provincial Directorate of Health - Available online at www.northclinist.com 
TABLE1. Classification of urticaria

\begin{tabular}{|c|c|c|}
\hline Type & Duration & Characteristic features \\
\hline Acute urticaria & \multicolumn{2}{|l|}{ Less than 6 weeks } \\
\hline Chronic spontaneous urticaria & \multirow[t]{2}{*}{ More than 6 weeks } & \multirow[t]{2}{*}{ Recurs at least 2 times a week. } \\
\hline Chronic inducible urticaria & & \\
\hline \multirow[t]{10}{*}{ (Chronic physical urticaria) } & \multirow{10}{*}{ More than 6 weeks } & Subtypes of urticaria according to triggering factors \\
\hline & & - Dermatographic urticaria \\
\hline & & - Cold urticaria \\
\hline & & - Heat urticaria \\
\hline & & - Delayed pressure urticaria \\
\hline & & - Solar urticaria \\
\hline & & - Vibration urticaria \\
\hline & & - Aquagenic urticaria \\
\hline & & - Contact urticaria \\
\hline & & - Cholinergic urticaria \\
\hline Episodic chronic urticaria & Lasts more than 6 weeks & Recurs at least 2 times a week. \\
\hline
\end{tabular}

sophils, causing the release of many mediators, primarily histamine. As a result, edema due to erythema and increased permeability secondary to vasodilatation [6]. Mast cells cannot be restimulated until regranulation after degranulation, which explains why the urticaria plate does not reappear for several days on the region.

In chronic urticaria, the antigen entering the body binds to the IgE high affinity (FceRIa) Fc receptor located on the mast cells and circulating basophils in the skin and degranulation from these cells occurs. When the same antigen is encountered for the $2^{\text {nd }}$ time, these $\mathrm{IgE}$ antibodies that are already present on the mast cells and basophils immediately bind to the antigen and develop an allergic reaction more quickly [7]. This shows us that autoimmunity is also important in chronic urticaria.

\section{Etiology}

Many factors may be responsible in the etiology of the disease. Often, encountered factors include:

1. Medications: Any drug may cause urticaria. However, the most commonly encountered ones are penicillin, aspirin, nonsteroidal anti-inflammatory drugs, sulfonamides, thiazide diuretics, oral contraceptives, angiotensin-converting enzyme inhibitors, vitamins, codeine, morphine, curare and its derivatives, synthetic adrenocorticotropic hormone, and radiocontrast substances. It may manifest from $1-2 \mathrm{~h}$ to 15 days after oral intake. Urticaria related to the drugs given intravenously will occur immediately. While the drugs generally cause acute urticaria, they may cause emergence or exacerbation of CSU [8].

2. Foods: Foods often encountered as causes of urticaria include nuts, eggs, fish, seafood, chocolate, meat, cow's milk, fruits (citrus fruits, grapes, plums, pineapples, bananas, apples, and strawberries), vegetables (tomatoes, garlic, onions, peas, beans, and carrots), mushrooms, fermented foods, spices, and spirits. Preservatives such as azo dyes, benzoic acid derivatives, and salicylates and food dyes are also important causative factors. Urticaria is usually seen $1-2 \mathrm{~h}$ after ingestion. Foodrelated urticarial rashes are more common in children [9]. Although it is accepted that foods have a place in the etiology of acute urticaria, their roles in the etiology of CSU have been not proven yet. It is thought that mostly pseudoallergens are involved in CSU, and therefore, diet is recommended for these patients [10].

3. Respiratory allergens: Pollen, mold spores, mites, animal dandruff, and hairs may cause urticaria when taken through the respiratory tract [11]. Smoking is also an important factor since it contains many chemicals and can worsen the urticaria, hives should be advised to stop smoking. Urticaria caused by respiratory allergens usually occurs immediately after contact.

4. Infections: Respiratory infections such as sinusitis, tonsillitis, dental abscesses, urinary tract infections, hepatitis, infectious mononucleosis, and parasites may cause urticaria [12]. Parasitoses are the cause of urticaria, especially in children.

5. Contact urticaria: Latex, cosmetics, and chemicals may cause urticaria by contact [13]. 
6. Insect bites: They should be questioned, especially in children [14].

7. Psychogenic factors: Reasons such as stress, sadness, and depression may aggravate the preexisting urticaria and also induce urticaria [15].

8. Systemic diseases: They may cause especially chronic urticaria. The presence of thyroid diseases and rheumatic diseases such as systemic lupus erythematosus, lymphoma, leukemia, and carcinomas may be investigated as required. It should be noted that urticaria may occur also in pregnant women [11].

9. Physical factors: Urticaria may develop due to external factors such as pressure, hot, cold, and dermographism [13]. Urticaria secondary to pressure generally manifests an average of 3-4 h after exposure to pressure. Therefore, they are termed as delayed pressure urticaria.

10.Hereditary: Hereditary urticaria is seen in types of urticaria as angioedema and familial cold urticaria.

11.Idiopathic urticaria without any known cause may be also seen.

\section{Clinic Manifestations}

The urticarial plaque has three characteristics as characteristic redness, blistering, and itching. Sometimes, a burning sensation may accompany. Lesions can occur anywhere in the body and recover in approximately 2-3 $\mathrm{h}$ without leaving a trace. This spontaneous recovery can sometimes last up to 1 day.

In angioedema, especially in areas such as eyelid and lip mucosae, there is a sudden-onset skin swelling. Pain and burning sensation may be at the forefront rather than pruritus. The lesions regress spontaneously in about $72 \mathrm{~h}$ [16].

Dermographism is an erythema and edema occurring about $10-20 \mathrm{~min}$ after applying mechanical trauma to the skin. While this situation may be encountered in almost half of the population, if this region is itchy, then this entity is called dermatographic urticaria. This condition is seen in about $4 \%$ of the society [13].

\section{Diagnosis and Differential Diagnosis}

It is quite easy to diagnose based on clinical appearance and anamnesis. However, it is also sometimes confused with drug eruptions, viral rashes, connective tissue diseases, photosensitive diseases, urticaria pigmentosa, urticarial vasculitis, and a number of syndromic diseases [17].

It is very important to obtain detailed anamnesis from the urticaria patient to reach the etiology. The patient should be asked about the time of onset, development, localization of lesions, systemic complaints, food intake, stress, and regular or occasional medication use. There is no need for routine laboratory tests and allergy tests in acute urticaria. In a guideline published in the United States, it has been reported that if there is no evidence to support a diagnosis, then there is no need for laboratory examinations [3]. Just $25 \%$ of acute urticaria cases become chronic in time [18].

\section{Treatment}

\section{Basic steps in the treatment}

Elimination of detectable etiologic causes and avoiding triggers constitute the first step of treatment. If the patient expresses that the lesions occur in any condition, such as after a drug or food intake, he must avoid this situation. If there is a noticeable infectious condition, it should be treated.

In an important subgroup of patients with chronic urticaria, exacerbations triggered by physical stimuli occur. Training patients can help them avoid these stimuli or understand their symptoms. As an example, heat (hot showers and excessive humidity) is the common trigger of many people. Tight clothing or rubber bands may exacerbate symptoms. On the other hand, physical urticaria (dermographism, cold, hot, solar, cholinergic, pressure urticaria, etc.) developed with the stimuli of physical factors should be properly diagnosed and the stimulant should be eliminated.

Many drugs, especially aspirin and nonsteroidal antiinflammatory drugs, may worsen symptoms. It is best to stay away from these drugs during this period [19].

A 4-week elimination diet is recommended for pseudoallergens thought to induce urticaria. Alcohol consumption is not recommended [20].

Concomitant stress, sleep disturbance, infections, premenstruation, and irregular antihistamine use may also aggravate the disease [15].

Rarely reported triggers are cigarette smoke, house dust mites, pollens, molds, and spores, and the patient should be informed about all these possible irritants [11].

After warning the patient about these issues, it is necessary to control the symptoms by suppressing the mediator release as the second step of the treatment.

In the treatment of urticaria (with or without angioedema), the focus should be on the immediate relief of pruritus and angioedema, if any. Approximately two-thirds of the cases of acute urticaria may be spontaneously confined and recover spontaneously. 


\section{H1 antihistamines}

Antihistamines bind to histamine receptors and prevent the formation of pruritus and urticarial plaques [19]. The old generations of antihistamines are called the first generation and the new generations are called the second generation as follows:

1. First-generation agents (e.g., diphenhydramine, chlorpheniramine, hydroxyzine, cyclizine, dimenhydrinate, doxepin, doxamine, meclizine, promethazine, etc.)

2. Second-generation agents (cetirizine, loratadine, fexofenadine, desloratadine, levocetirizine, ebastine, and bilastine).

In the treatment, the second-generation $\mathrm{H} 1$ antihistamines are preferred. The first-generation $\mathrm{H} 1$ antihistamines are less preferred due to their significant sedation and side effects and short duration of action [21].

Antihistamines should be used on a daily basis but not in case of need. There is not yet sufficient data to suggest the most effective antihistamine in the treatment of CSU. The response to antihistamines and the possible side effects may vary from person to person.

The second-generation agents are more often preferred for both adults and children due to their low side effects, less drug-drug interaction, anticholinergic effects, longer duration of action, and higher safety [22].

Some patients may need higher dosages (up to 4 times) than standard doses for the control of urticarial symptoms and may experience drowsiness and sedation as side effects at high doses.

\section{$\mathrm{H} 2$ antihistamines}

Combination of $\mathrm{H} 1$ and $\mathrm{H} 2$ antihistamines may be more effective for acute urticaria than $\mathrm{H} 1$ antihistamines alone. However, the use of $\mathrm{H} 2$ in recent years has been removed from some guidelines [23]. H2 antihistamine options include ranitidine, nizatidine, famotidine, and cimetidine; however, cimetidine may increase levels of other drugs so it should be used with caution.

\section{Systemic corticosteroids}

Glucocorticoids do not inhibit mast cell degranulation, but they probably act by suppressing various inflammatory mechanisms. Glucocorticoids are not considered necessary for isolated urticaria. However, systemic glucocorticoids should be considered in cases with significant angioedema or if the symptoms persist for more than a few days and cannot be controlled by antihistamines. To control persistent and severe symptoms, systemic glucocorticoids may be added to antihistaminic therapy for a short period of time [19]. In adults, prednisone is given for an average of 5-10 days at daily doses of 30-60. In children, daily dose of prednisolone is $0.5-1 \mathrm{mg} / \mathrm{kg}$ (maximum $60 \mathrm{mg} /$ day) which is tapered and discontinued within $5-7$ days.

\section{Cyclosporine}

Compared with systemic corticosteroids, cyclosporine (5 $\mathrm{mg} / \mathrm{kg} /$ day) has been reported to cause a more rapid and long-term remission. Clinical response rates are between $64 \%$ and $95 \%$. When the duration of the treatment is completed, $50 \%$ of the patients may have remissions up to 9 months, but in some patients, relapses may occur after discontinuation of the treatment. In this case, maintenance therapy can be maintained at doses of 1.5-2 $\mathrm{mg} / \mathrm{kg} /$ day for up to 2 years. The longer the duration of use, the higher the risk of side effects. It is used as an off-label drug for the treatment of CSU [24]. Although cyclosporine is a highly effective agent in the treatment of CSU, it should be preferred in patients with chronic urticaria resistant to high-dose antihistamines and omalizumab treatment, especially due to the risk of side effects that may occur during long-term use.

\section{Omalizumab}

Omalizumab, a monoclonal antibody (anti-IgE IgG) against $\mathrm{IgE}$, is safe and effective for many patients, but it is too expensive and does not appear to have long-term disease-improving effects. Omalizumab reduces mast cell function and induces eosinophil apoptosis. It reduces cytokine release from basophils and migration of immune cells to tissue [25]. There are no studies directly comparing omalizumab with other treatments for resistant chronic urticaria.

There is no need for laboratory tests before and during the treatment. It is administered subcutaneously at a dose of $300 \mathrm{mg}$ every 28 days for 6 months. It is effective in $>80 \%$ of the patients. Omalizumab has also been reported to be effective in the treatment of other forms of urticaria, such as cold urticaria, solar urticaria, cholinergic urticaria, symptomatic dermatographic, and urticarial vasculitis [26].

Omalizumab is the only approved, effective, and reliable treatment option for CSU patients with persistent symptoms despite high-dose antihistamine therapy. In case of recurrence after 6 months of use, it can be used again without loss of efficacy [27].

\section{Leukotriene receptor antagonists (LTRAs)}

Zafirlukast and montelukast have not been studied in the treatment of acute urticaria. There is no double- 
blind, placebo-controlled study with LTRAs. Systematic reviews indicate that they are more effective than placebo, but they are not highly recommended except for aspirininduced urticaria cases. These drugs can be added to the treatment in step 2 and 3 [28].

\section{Other treatments}

The studies performed on the effectiveness of anti-inflammatory drugs such as dapsone, sulfasalazine, hydroxychloroquine, and colchicine, and studies on the effectiveness of immunosuppressive drugs such as methotrexate, mycophenolate mofetil, azathioprine, tacrolimus, mizoribine, and cyclophosphamide have low level of evidence $[29,30]$.

Several algorithms have been developed for the treatment of urticaria, which are summarized in Tables 2 and 3.

TABLE2. Treatment algorithm for urticaria recommended by EAACI, GA2LEN, EDF, WOA [3]

First-line

Second-generation $\mathrm{H} 1$ antihistamines

I If symptoms persist more than 2 weeks

Second-line

Increase the dose of second-generation antihistamines up to 4 times

If symptoms persist for additional 1-4 weeks

Third-line

Add omalizumab, montelukast or cyclosporine

If symptoms cannot be controlled, corticosteroid therapy may be used for up to 10 days.

EAACI: European Academy of Allergology and Clinical Immunology; EDF: European Dermatology Forum; GA2LEN: Global Allergy and Asthma European Network; WAO: World Allergy Organization.

\section{Treatment of urticaria in children}

New generation $\mathrm{H} 1$ antihistamines are recommended as the first choice in the treatment of urticaria as long-term safety profiles are better. The first-generation $\mathrm{H} 1$ antihistamines should not be used because they have strong sedative effects and decreased psychomotor ability of the children. Antihistaminic doses can be increased up to 2 times by taking the body weight of the children into account in cases refractory to standard doses [32].

There are no sufficient data on the use of LTRAs, cyclosporine, and omalizumab in the treatment of urticaria in children. Based on the treatment of adult urticaria, these agents may be used in addition to antihistamines in the third step of treatment. Evidence for the effectiveness and safety of omalizumab is increasing in children over 7 years of age. Pediatric patients who very well tolerated to monthly doses of $150-300 \mathrm{mg}$ have been reported in the literature [33].

Cyclosporine has been used in children who are unresponsive to antihistaminic therapy as in adults and has been found to be highly effective [34].

Systemic corticosteroids can be used for a maximum of 10 days in pediatric patients experiencing angioedema attacks or widespread severe urticaria.

Treatment of urticaria during pregnancy and lactation In the latest treatment guidelines, it is stated that the classical treatment algorithm proposed in the treatment of urticaria in pregnancy can be applied [8]. The pregnancy category $B$ is indicated for chlorpheniramine, loratadine, cetirizine and levocetirizin is the pregnancy and category $\mathrm{C}$ for all other antihistamines. Immediate use of the first-generation $\mathrm{H} 1$ antihistamines with sedative effect has been found to be inconvenient as it causes

TABLE 3. Treatment algorithm recommended by the Dermato-allergy Working Group of the Turkish Society of Dermatology and the Turkish Dermato-immunology and Allergy Association [8]

Step $1 \quad$ Start with standard doses of second-generation antihistamines

Step 2 If not under control 1-2 weeks later, increase the dose up to 4 times

Step 3 If not under control 1-2 weeks later, switch to another antihistamine and use complete dose of the drug

Step 4 If not under control 1-2 weeks later, switch to omalizumab for up to 24 weeks

Step 5 If not under control 24 weeks later, increase the dose of omalizumab, switch to cyclosporine, or add to the existing treatment

Step 6 If symptoms are still not under control 12 weeks later, other agents may be tried

In selected cases, a leukotriene receptor antagonist may be added in Steps 2 and 3. During attacks, $0.5-1 \mathrm{mg} / \mathrm{kg}$ prednisolone or the equivalent systemic steroid may be prescribed. 
respiratory depression in the infant. All current guidelines emphasize that new generation antihistamines are more reliable in the treatment of urticaria in pregnant patients [8].

Pregnancy categories $\mathrm{B}$ and $\mathrm{C}$ are, respectively, assigned for LTRAs and cyclosporine.

There is no experience in the use of omalizumab in pregnancy. While using omalizumab, 169 pregnancies were reported in asthmatic patients, without increase in major anomalies. The FDA classified omalizumab in pregnancy category B [35].

Loratadine and cetirizine may be preferred during the breastfeeding period because they are found in very low amounts in breast milk [8].

\section{Treatment of angioedema}

Angioedema is not only seen as swelling in the skin and lips but sometimes also causes swelling in the tongue and larynx and may be life threatening. Therefore, treatment of angioedema is important. First of all, make sure that the patient's airway is open and he/she is breathing comfortably. The standard treatment for patients without respiratory distress is $\mathrm{H} 1$ and $\mathrm{H} 2$ antihistamines and systemic corticosteroids [36]. If the patient has airway constriction or hypotension, the epinephrine should be administered intramuscularly at a dose of $0.2-0.5 \mathrm{mg}$ [37]. The patient with respiratory distress should be immediately referred to a more experienced medical center after taking the necessary precautions.

\section{Conclusion}

Urticaria is an acute and chronic itchy rash that can be quite irritating. Angioedema may accompany urticaria, and rarely, it may be fatal. Although many etiologic factors such as infections, drugs, and foods are blamed in their etiology, they are often idiopathic. In the treatment of patients, if there is a detectable etiologic or trigger factor, it should be avoided and the patient should be warned for the possible existence of physical urticaria. Although antihistamines are used in the first step treatment, a wide variety of agents have been used, including corticosteroids, omalizumab, and cyclosporine. In medicine, there is no disease, there is a patient, and every patient should be treated with appropriate care. Nevertheless, it should be kept in mind that it is still a challenging disease for both the patient and the physician.
Conflict of Interest: No conflict of interest was declared by the authors.

Financial Disclosure: The authors declared that this study has received no financial support.

Authorship Contributions: Concept - M.A.K., N.A.; Design M.A.K., N.A.; Supervision - M.A.K., N.A.; Materials - M.A.K., N.A.; Data collection \&/or processing - M.A.K., N.A.; Analysis and/or interpretation - M.A.K., N.A.; Writing - M.A.K., N.A.; Critical review - M.A.K., N.A.

\section{REFERENCES}

1. Darlenski R, Kazandjieva J, Zuberbier T, Tsankov N. Chronic urticaria as a systemic disease. Clin Dermatol 2014;32:420-3. [CrossRef]

2. Sánchez-Borges M, Asero R, Ansotegui IJ, Baiardini I, Bernstein JA, Canonica GW, et al; WAO Scientific and Clinical Issues Council. Diagnosis and treatment of urticaria and angioedema: a worldwide perspective. World Allergy Organ J 2012;5:125-47. [CrossRef]

3. Zuberbier T, Aberer W, Asero R, Bindslev-Jensen C, Brzoza Z, Canonica GW, et al; European Academy of Allergy and Clinical Immunology; Global Allergy and Asthma European Network; European Dermatology Forum; World Allergy Organization. The EAACI/GA(2) LEN/ EDF/WAO Guideline for the definition, classification, diagnosis, and management of urticaria: the 2013 revision and update. Allergy 2014;69:868-87. [CrossRef]

4. Önder M. Ürtiker ve anjioödem, genel yaklaşım ve sınıflandırma. Turkiye Klinikleri J Dermatol-Special Topics 2008;1:6-11.

5. Wedi B. Urticaria. J Dtsch Dermatol Ges 2008;6:306-17. [CrossRef]

6. Sabroe RA, Greaves MW. The pathogenesis of chronic idiopathic urticaria. Arch Dermatol 1997;133:1003-8. [CrossRef]

7. Aslan Kayıran M, Akdeniz N. Intracutaneous tests (Type 1 allergy test, Type 4 allergy test). Turkiye Klinikleri J Dermatol-Special Topics 2017;10:13-8.

8. Kocatürk Göncü E, Aktan Ş, Atakan N, Bülbül Başkan E, Erdem T, Koca $\mathrm{R}$ et al. Türkiye Ürtiker Tanı ve Tedavi Kılavuzu-2016. Turkderm- Arch Turk Dermatol Venerology 2016;50:82-98.

9. Sampson HA. Adverse reactions to foods. In: Adkinson NF Jr., Yunginger JW, Busse WW, Bochner BS, Holgate ST, Simons ER, editors. Middleton's Allergy Principles and Practice. 6th ed. Philadelphia: Mosby; 2003. p. 1619-43.

10. Rajan JP, Simon RA, Bosso JV. Prevalence of sensitivity to food and drug additives in patients with chronic idiopathic urticaria. J Allergy Clin Immunol Pract 2014;2:168-71. [CrossRef]

11. Chow SK. Management of chronic urticaria in Asia: 2010 AADV consensus guidelines. Asia Pac Allergy 2012;2:149-60. [CrossRef]

12. Bülbül Başkan E. Etiology and Pathogenesis of Chronic Urticaria. Turkiye Klinikleri J Dermatol-Special Topics 2015;8:13-9.

13. Aktan Ş. Physical Urticarias: Pathogenesis and Diagnostic Testing Turkiye Klinikleri J Dermatol-Special Topics 2015;8:34-40.

14. Sánchez-Borges M, Capriles-Hulett A, Caballero-Fonseca F, GonzálezAveledo L. Urticaria in children attending allergy services. [Article in Spanish]. Rev Alerg Mex 2014;61:90-8.

15. Staubach P, Dechene M, Metz M, Magerl M, Siebenhaar F, Weller $\mathrm{K}$, et al. High prevalence of mental disorders and emotional distress in patients with chronic spontaneous urticaria. Acta Derm Venereol 2011;91:557-61. [CrossRef]

16. Kaplan AP. Clinical practice. Chronic urticaria and angioedema. N 
Engl J Med 2002;346:175-9. [CrossRef]

17. Giménez-Arnau A, Ferrer M, Bartra J, Jáuregui I, Labrador-Horrillo $\mathrm{M}$, Frutos JO, et al. Management of chronic spontaneous urticaria in routine clinical practice: A Delphi-method questionnaire among specialists to test agreement with current European guidelines statements. Allergol Immunopathol (Madr) 2017;45:134-44. [CrossRef]

18. Arch Dermatol. 1998 Mar;134(3):319-23. Acute urticaria in infancy and early childhood: a prospective study. Mortureux $\mathrm{P}$, Léauté-Labrèze C, Legrain-Lifermann V, Lamireau T, Sarlangue J, Taïeb A.

19. Bernstein JA, Lang DM, Khan DA, Craig T, Dreyfus D, Hsieh F, et al. The diagnosis and management of acute and chronic urticaria: 2014 update. J Allergy Clin Immunol 2014;133:1270-7. [CrossRef]

20. Buhner S, Reese I, Kuehl F, Lochs H, Zuberbier T. Pseudoallergic reactions in chronic urticaria are associated with altered gastroduodenal permeability. Allergy 2004;59:1118-23. [CrossRef]

21. Lang DM. Evidence-based diagnosis and treatment of chronic urticaria/angioedema. Allergy Asthma Proc 2014;35:10-6. [CrossRef]

22. Mahdy AM, Webster NR. Histamine and antihistamines. In: Pharmacology. Elsevier Ltd; 2011. p. 324-9.

23. Fedorowicz Z, van Zuuren EJ, Hu N. Histamine H2-receptor antagonists for urticarial. Cochrane Database Syst Rev 2012:CD008596.

24. Vena GA, Cassano N, Colombo D, Peruzzi E, Pigatto P; Neo-I-30 Study Group. Cyclosporine in chronic idiopathic urticaria: a doubleblind, randomized, placebo-controlled trial. J Am Acad Dermatol 2006;55:705-9. [CrossRef]

25. Maurer M, Rosén K, Hsieh HJ, Saini S, Grattan C, Gimenéz-Arnau A, et al. Omalizumab for the treatment of chronic idiopathic or spontaneous urticaria. N Engl J Med 2013;368:924-35. [CrossRef]

26. Giménez-Arnau AM, Toubi E, Marsland AM, Maurer M. Clinical management of urticaria using omalizumab: the first licensed biological therapy available for chronic spontaneous urticaria. J Eur Acad Dermatol Venereol 2016;30 Suppl 5:25-32. [CrossRef]
27. Metz M, Ohanyan T, Church MK, Maurer M. Retreatment with omalizumab results in rapid remission in chronic spontaneous and inducible urticaria. JAMA Dermatol 2014;150:288-90. [CrossRef]

28. Kaplan AP. Chronic Spontaneous Urticaria: Pathogenesis and Treatment Considerations. Allergy Asthma Immunol Res 2017;9:477-82.

29. McGirt LY, Vasagar K, Gober LM, Saini SS, Beck LA. Successful treatment of recalcitrant chronic idiopathic urticaria with sulfasalazine. Arch Dermatol 2006;142:1337-42. [CrossRef]

30. Reeves GE, Boyle MJ, Bonfield J, Dobson P, Loewenthal M. Impact of hydroxychloroquine therapy on chronic urticaria: chronic autoimmune urticaria study and evaluation. Intern Med J 2004;34:182-6. [CrossRef]

31. Fitzsimons R, van der Poel LA, Thornhill W, du Toit G, Shah N, Brough HA. Antihistamine use in children. Arch Dis Child Educ Pract Ed 2015;100:122-31. [CrossRef]

32. Del Cuvillo A, Sastre J, Montoro J, Jáuregui I, Ferrer M, Dávila I, et al. Use of antihistamines in pediatrics. J Investig Allergol Clin Immunol 2007;17 Suppl 2:28-40.

33. Goldstein S, Gabriel S, Kianifard F, Ortiz B, Skoner DP. Clinical features of adolescents with chronic idiopathic or spontaneous urticaria: Review of omalizumab clinical trials. Ann Allergy Asthma Immunol 2017;118:500-4. [CrossRef]

34. Doshi DR, Weinberger MM. Experience with cyclosporine in children with chronic idiopathic urticaria. Pediatr Dermatol 2009;26:409-13.

35. Namazy J, Cabana MD, Scheuerle AE, Thorp JM Jr, Chen H, Carrigan G, et al. The Xolair Pregnancy Registry (EXPECT): the safety of omalizumab use during pregnancy. J Allergy Clin Immunol 2015;135:407-12.

36. Moellman JJ, Bernstein JA, Lindsell C, Banerji A, Busse PJ, Camargo $\mathrm{CA} \mathrm{Jr}$, et al. A consensus parameter for the evaluation and management of angioedema in the emergency department. Acad Emerg Med 2014;21:469-84. [CrossRef]

37. Tang AW. A practical guide to anaphylaxis. Am Fam Physician 2003;68:1325-32. 